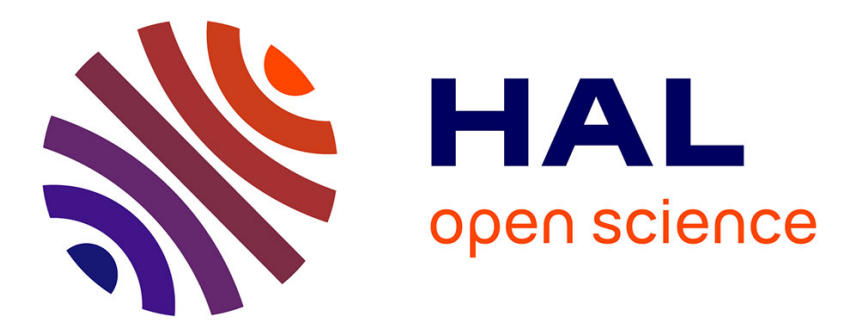

\title{
Improved performances of catalytic G-quadruplexes (G4-DNAzymes) via the chemical modifications of the DNA backbone to provide G-quadruplexes with double 3'-external G-quartets
}

Antonella Virgilio, Veronica Esposito, Pauline Lejault, David Monchaud, Aldo Galeone

\section{To cite this version:}

Antonella Virgilio, Veronica Esposito, Pauline Lejault, David Monchaud, Aldo Galeone. Improved performances of catalytic G-quadruplexes (G4-DNAzymes) via the chemical modifications of the DNA backbone to provide G-quadruplexes with double 3'-external G-quartets. International Journal of Biological Macromolecules, 2020, 151 (976-983), 10.1016/j.ijbiomac.2019.10.181 . hal-02372450

\author{
HAL Id: hal-02372450 \\ https://hal.science/hal-02372450
}

Submitted on 21 Nov 2019

HAL is a multi-disciplinary open access archive for the deposit and dissemination of scientific research documents, whether they are published or not. The documents may come from teaching and research institutions in France or abroad, or from public or private research centers.
L'archive ouverte pluridisciplinaire HAL, est destinée au dépôt et à la diffusion de documents scientifiques de niveau recherche, publiés ou non, émanant des établissements d'enseignement et de recherche français ou étrangers, des laboratoires publics ou privés. 


\title{
Improved performances of catalytic G-quadruplexes (G4-DNAzymes) via the chemical modifications of the DNA backbone to provide G-quadruplexes with double 3'-external G-quartets
}

\author{
Antonella Virgilio, ${ }^{\# a}$ Veronica Esposito, ${ }^{\# a}$ Pauline Lejault, ${ }^{b}$ David Monchaud ${ }^{* b}$ and Aldo Galeone ${ }^{* a}$ \\ ${ }^{a}$ Department of Pharmacy, University of Naples Federico II, Napoli, Italy.E-mail: galeone@ unina.it. ${ }^{b}$ ICMUB CNRS \\ UMR6302, UBFC Dijon, 9, Avenue Alain Savary, 21078 Dijon, France. E-mail: david.monchaud@ cnrs.fr. " These \\ authors contributed equally. * Corresponding authors
}

\begin{abstract}
Here we report on the design of a new catalytic G-quadruplex-DNA system (G4-DNAzyme) based on the modification of the DNA scaffold to provide the DNA pre-catalyst with two identical 3'-ends, known to be more catalytically proficient than the 5'-ends. To this end, we introduced a 5 '-5' inversion of polarity site in the middle of the G4-forming sequences $A_{4} A$ and $A_{6} A$ to obtain $d\left({ }^{3} A G G^{5^{\prime}}\right.$ -

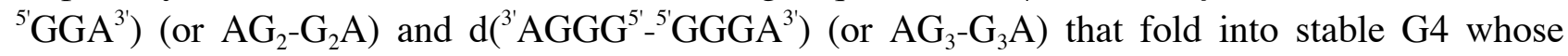
tetramolecular nature was confirmed via nuclear magnetic resonance (NMR) and circular dichroism (CD) investigations. Both $\mathrm{AG}_{2}-\mathrm{G}_{2} \mathrm{~A}$ and $\mathrm{AG}_{3}-\mathrm{G}_{3} \mathrm{~A}$ display two identical external G-quartets (3'-ends) known to interact with the cofactor hemin with a high efficiency, making the resulting complex competent to perform hemoprotein-like catalysis (G4-DNAzyme). A systematic comparison of the performances of modified and unmodified G4s lends credence to the relevance of the modification exploited here (5'-5' inversion of polarity site), which represents a new chemical opportunity to improve the overall activity of catalytic G4s.
\end{abstract}

\section{KEYWORDS}

DNAzyme; Tetramolecular G-quadruplex; Peroxidase activity; hemin.

\section{INTRODUCTION}

The catalytic activity of quadruplex-DNA (G4), often referred to as quadruplex DNAzyme or G4DNAzyme, was discovered as an aftermath of investigations aiming at identifying aptamers prone to catalyze porphyrin metalation [1]. Given that N-methylmesoporphyrin IX (NMM) is a known transition-state analogue for porphyrin metalation, Sen et al. searched for aptamers with a high NMM affinity [2]. Systematic evolution of ligands by exponential enrichment (SELEX) experiments lead to the identification of a 24-nt DNA named PS5.M that binds NMM with exquisite affinity. As expected, PS5.M catalyses the metalation of mesoporphyrin IX but it was also discovered that this catalytic activity is inhibited by protoporphyrin IX iron(III) chloride, or hemin (Fig. 1), owing to the formation of a high-stability PS5.M/hemin complex. Given that hemin is a known cofactor of many enzymes (heme-dependent enzymes, or hemoenzymes), the hemoprotein-like properties of PS5.M were investigated: like peroxidases, the presence of a stoichiometric oxidant (hydrogen peroxide, $\mathrm{H}_{2} \mathrm{O}_{2}$ ), was found to strongly increase the PS5.M/hemin complex-mediated oxidation rate of a model substrate, the chromogenic ABTS (Fig. 1), or 2,2'-azino-bis(3-ethylbenzothiazoline-6-sulfonic acid [3]. These results provided the proof-of-concept that nucleic acids can perform oxidase-type catalysis. The G4-DNAzyme nature of this novel system was demonstrated later on: both the nature of the sequence of PS5.M d( $\left.{ }^{5} \mathrm{GTG}_{3} \mathrm{TCAT}_{2} \mathrm{GTG}_{3} \mathrm{TG}_{3} \mathrm{TGTG}_{2}{ }^{3^{\prime}}\right)$ and the dependence of its catalytic activity upon $\mathrm{K}^{+}$-rich buffers were indeed strongly suggestive of a G4 pre-catalyst [4]. The hypothesis, which is now widely accepted, was that G4 offers a binding site to hemin, which becomes catalytically proficient only upon interaction with the external G-quartet of the DNA pre-catalyst (Fig. 1). It is intriguing that, more than three decades after its discovery, the exact mechanism of G4-DNAzyme is 
still unclear and debated [5-8]. Despite this, dozens of new G4-DNAzymes are reported yearly [912] with multiple biosensing applications $[13,14]$ ranging from metal detection [15-18] to mRNA detection $[19,20]$, now resolutely pointing towards industry-relevant applications .
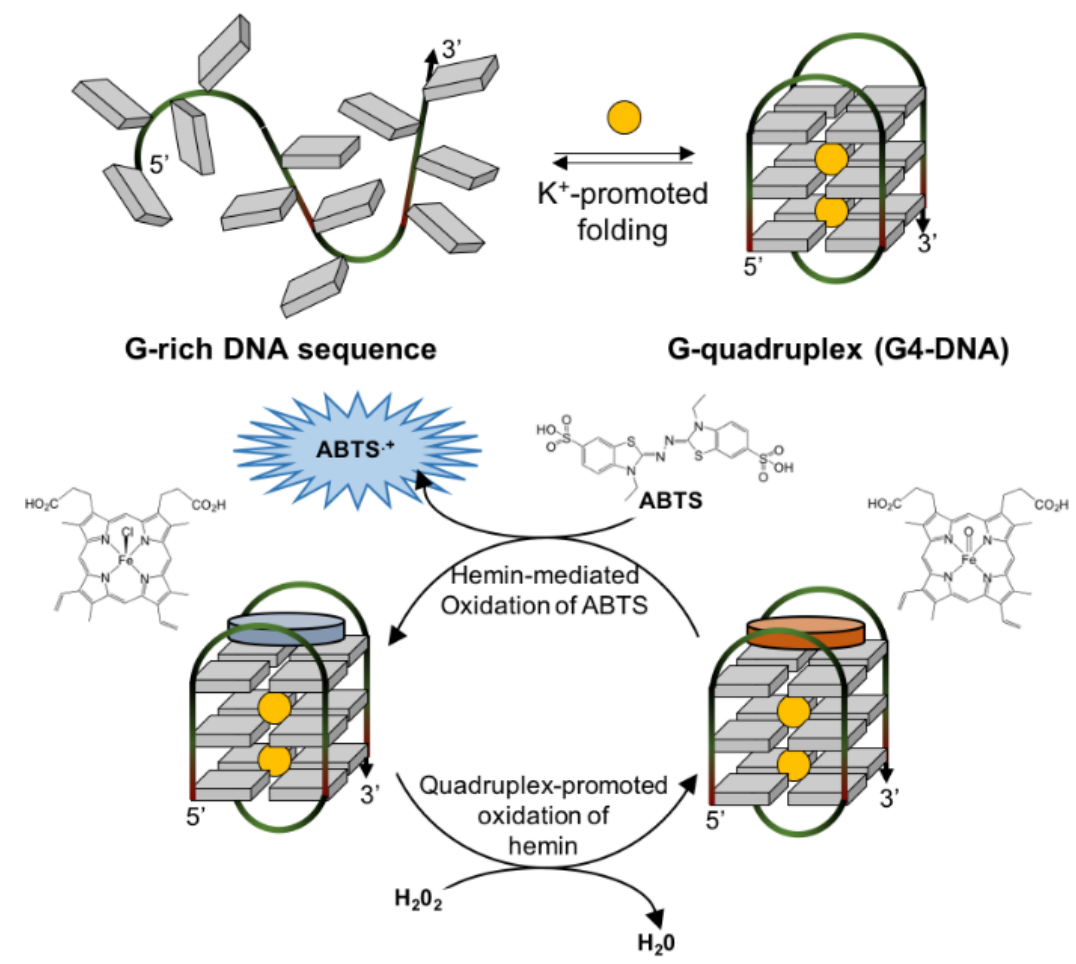

Fig 1. Schematic representation of the folding of a guanine $(G)$-rich DNA sequence into a G-quadruplex-DNA (G4-DNA, upper panel), and of a G4-DNAzyme catalysis, here the $\mathrm{H}_{2} \mathrm{O}_{2}$-promoted oxidation of ABTS.

Over the past years, various strategies have been devised to improve the overall catalytic efficiency of G4-DNAzymes and make them competitive with hemoproteins. The effects of the modification of the sequence and thus, of the structure of the G4 pre-catalysts have been studied [21,22], along with those of external G-quartet flanking nucleotides [23-25]. The addition of external boosting agents has also been studied (such as adenine triphosphate (ATP) $[5,26]$, template-assembled synthetic Gquartet (TASQ) [27] or spermine [28]) as well as the conjugation of ligand-binding aptamer (i.e., the 'nucleoapzyme' approach [29]). The role of the temperature was also investigated: DNAzymes with better catalytic performances at elevated temperatures were uncovered (so called thermophilic G4DNAzymes) [30], on the basis of highly thermally stable tetramolecular G4 pre-catalysts. This approach is interesting in that it tackles one pitfalls usually associated with nucleic acid catalysts, i.e., their supposed sensitivity to harsh experimental conditions. Here, we report on a brand new approach aiming at using G4 pre-catalysts with two identical external G-quartets. Indeed, in all studies reported so far, G4s display different external quartets (so called 5'- and 3'-quartets, or 5'- and 3'-ends) while it has been demonstrated that the 3'-end is more catalytically competent than its 5'-counterpart [7]. We thus decide to design and synthesize G4s with two external 3'-ends (Fig. 2) according to an original approach based on the introduction of a $5^{\prime}-5^{\prime}$ inversion of polarity site in the middle of the G4-forming strands d( ${ }^{5^{\prime}} \mathrm{AGGGGA}^{3^{\prime}}$ ) (or $\mathrm{AG}_{4} \mathrm{~A}$ ) and d( ${ }^{5^{\prime}} \mathrm{AGGGGGGA}{ }^{3^{\prime}}$ ) (or $\left.\mathrm{AG}_{6} \mathrm{~A}\right)$, known to form an efficient G4-DNAzyme system. The catalytic dividend of this approach is three-fold: $i$ - the major role of the 3'-end in binding hemin, critical to promote the catalytic process efficiently; $i i$ - the high thermal stability of a tetramolecular quadruplex with inverted polarity, as already demonstrated with $\mathrm{d}^{\left({ }^{\prime}\right.} \mathrm{TGG}^{\left.5^{\prime}-{ }^{5} \mathrm{GGT}^{3}\right)}$ (or $\left.\mathrm{TG}_{2}-\mathrm{G}_{2} \mathrm{~T}\right)$ [31], to use them as thermophilic pre-catalysts; and iii- the beneficial presence of adenines (dA) on the 3'-end, which help hemin stacking and thus, the catalysis [7]. We thus report here on the synthesis of the 6- and 8-nt sequences $d\left({ }^{3} A_{G G} G^{5^{\prime}}-{ }^{5^{\prime}} G_{G A}{ }^{3^{\prime}}\right)\left({ }^{2} A_{2}-G_{2} A\right)$ and 
$\left.\mathrm{d}^{3^{\prime}} \mathrm{AGGG}^{5^{\prime}-5^{\prime}} \mathrm{GGGA}^{3^{\prime}}\right)$ (or $\mathrm{AG}_{3}-\mathrm{G}_{3} \mathrm{~A}$ ) that fold into G4s with two adenine-capped 3'-ends (Fig. 2), whose high thermal stability allows for their use as thermophilic DNAzyme pre-catalysts.

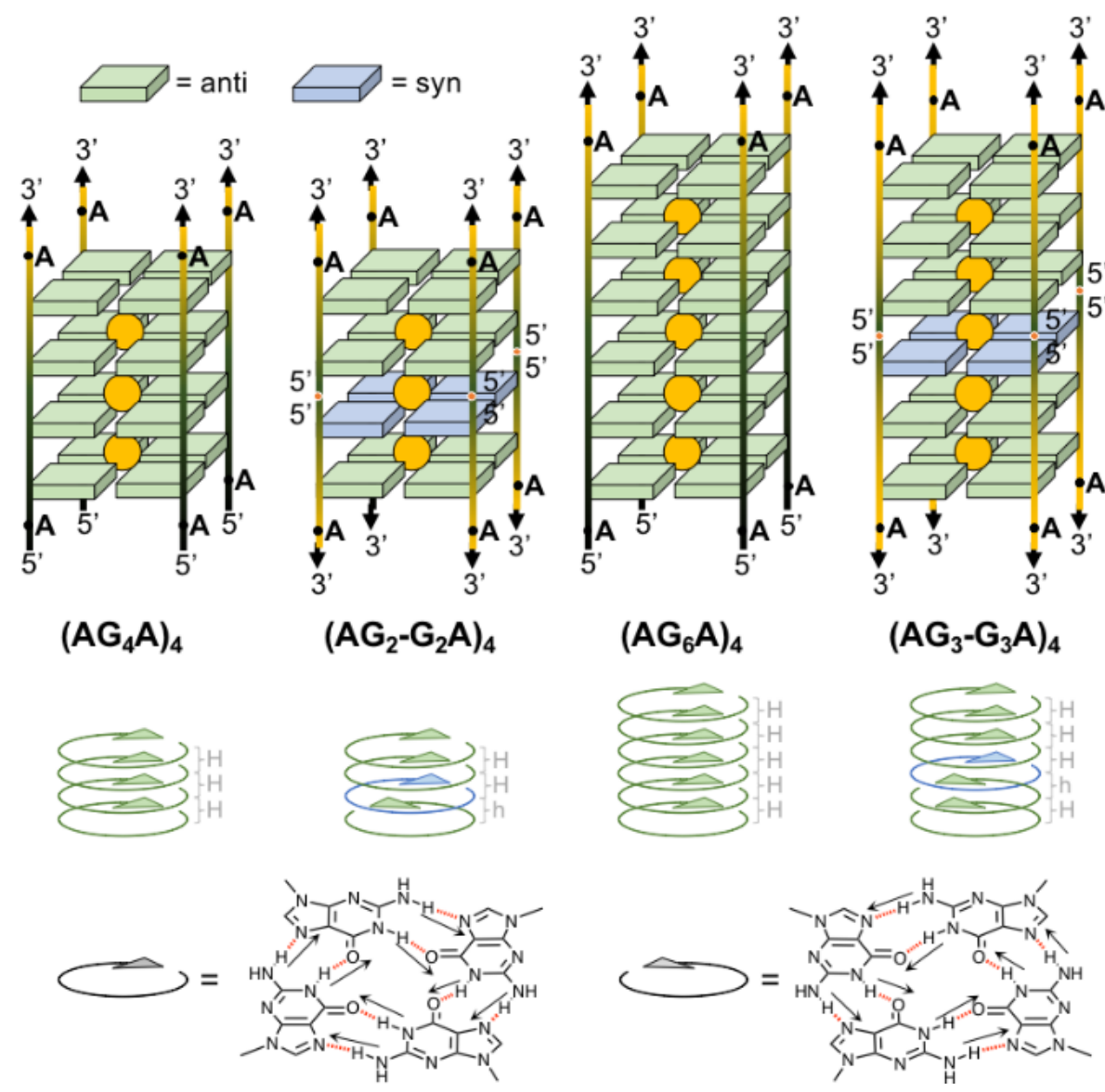

Fig. 2. Schematic representation of the G-quadruplex structures formed by $A_{4} A, A_{2}-G_{2} A, A_{6} A$ and $A G_{3}-G_{3} A$. Anti and syn residues are in green and blue, respectively. Details about the H-bond directionality of G-quartets; " $H$ " and " $h$ " for homopolar and heteropolar stacking, respectively.

\section{MATERIALS AND METHODS}

2.1. Oligonucleotide synthesis and purification. The modified oligonucleotides (ODNs) and their natural counterparts were synthesized on a Millipore Cyclone Plus DNA synthesizer using solid phase $\beta$-cyanoethyl phosphoramidite chemistry at $15 \mu \mathrm{mol}$ scale. The synthesis of the $3^{\prime}-5^{\prime}$ tracts were performed by using normal 3'-phosphoramidites, whereas the 5'-3' tracts were synthesized by using 5'-phosphoramidites. For all ODNs an universal support was used. The oligomers were detached from the support and deprotected by treatment with concentrated aqueous ammonia at $80^{\circ} \mathrm{C}$ overnight. The combined filtrates and washings were concentrated under reduced pressure, redissolved in $\mathrm{H}_{2} \mathrm{O}$, analyzed and purified by high-performance liquid chromatography on a Nucleogel SAX column (Macherey-Nagel, 1000-8/46), using buffer A: $20 \mathrm{mM} \mathrm{NaH} \mathrm{PO}_{4} / \mathrm{Na}_{2} \mathrm{HPO}_{4}$ aqueous solution (pH 7.0) containing $20 \%(\mathrm{v} / \mathrm{v}) \mathrm{CH}_{3} \mathrm{CN}$ and buffer B: $1 \mathrm{M} \mathrm{NaCl}, 20 \mathrm{mM} \mathrm{NaH} \mathrm{PO}_{4} / \mathrm{Na}_{2} \mathrm{HPO}_{4}$ aqueous solution (pH 7.0) containing 20\% (v/v) $\mathrm{CH}_{3} \mathrm{CN}$; a linear gradient from 0 to $100 \% \mathrm{~B}$ for $30 \mathrm{~min}$ and flow rate $1 \mathrm{ml} / \mathrm{min}$ were used. The fractions of the oligomers were collected and successively desalted by Seppak cartridges (C-18). The isolated oligomers proved to be $95 \%$ pure by NMR.

2.2. NMR Spectroscopy. NMR samples were prepared at a concentration of about $2.0 \mathrm{mM}$, in 0.6 $\mathrm{mL}\left(\mathrm{H}_{2} \mathrm{O} / \mathrm{D}_{2} \mathrm{O} 9: 1 \mathrm{v} / \mathrm{v}\right)$ buffer solution having $10 \mathrm{mM} \mathrm{KH_{2 }} \mathrm{PO}_{4} / \mathrm{K}_{2} \mathrm{HPO}_{4}, 40 \mathrm{mM} \mathrm{KCl}$ and $0.2 \mathrm{mM}$ EDTA (pH 7.0). All the samples were heated for $5-10 \mathrm{~min}$ at $90{ }^{\circ} \mathrm{C}$ and slowly cooled $(10-12 \mathrm{~h})$ to room temperature. The solutions were equilibrated for several weeks at $4{ }^{\circ} \mathrm{C}$. The annealing process was assumed to be complete when ${ }^{1} \mathrm{H}$ NMR spectra were superimposeable on changing time. NMR 
spectra were recorded with Varian Unity INOVA $500 \mathrm{MHz}$ spectrometer. 1D proton spectra of the sample in $\mathrm{H}_{2} \mathrm{O}$ were recorded using pulsed-field gradient DPFGSE for $\mathrm{H}_{2} \mathrm{O}$ suppression. ${ }^{1} \mathrm{H}$-chemical shifts were referenced relative to external sodium 2,2-dimethyl-2-silapentane-5-sulfonate (DSS). Pulsed-field gradient DPFGSE sequence was used for NOESY (180 ms and $80 \mathrm{~ms}$ mixing times) and TOCSY (120 ms mixing time) experiments in $\mathrm{H}_{2} \mathrm{O}$. All experiments were recorded using STATESTPPI procedure for quadrature detection. In all 2D experiments, the time domain data consisted of 2048 complex points in $\mathrm{t} 2$ and 400-512 fids in $\mathrm{t} 1$ dimension. A relaxation delay of $1.2 \mathrm{~s}$ was used for all experiments.

2.3. CD Spectroscopy. CD samples of modified oligonucleotides and their natural counterpart were prepared from stock solutions annealed under the same conditions as NMR and diluted just before the acquisition at a ODN concentration of $70 \mu \mathrm{M}$ by using a buffer solution $10 \mathrm{mM} \mathrm{KH} \mathrm{KO}_{4} / \mathrm{K}_{2} \mathrm{HPO}_{4}$, $40 \mathrm{mM} \mathrm{KCl}(\mathrm{pH} \mathrm{7.0)}$. CD spectra of all quadruplexes and CD melting curves were registered on a Jasco 715 CD spectrophotometer. For the CD spectra, the wavelength was varied from 220 to 320 $\mathrm{nm}$ at $100 \mathrm{~nm} \mathrm{~min}^{-1} \mathrm{scan}$ rate, and the spectra recorded with a response of $16 \mathrm{~s}$, at $2.0 \mathrm{~nm}$ bandwidth and normalized by subtraction of the background scan with buffer. The temperature was kept constant at $20^{\circ} \mathrm{C}$ with a thermoelectrically-controlled cell holder (Jasco PTC-348). CD melting curves were registered as a function of temperature (range: $20^{\circ} \mathrm{C}-95^{\circ} \mathrm{C}$ ) for all quadruplexes at their maximum Cotton effect wavelengths. The CD data were recorded in a $0.1 \mathrm{~cm}$ pathlength cuvette with a scan rate of $0.5^{\circ} \mathrm{C} / \mathrm{min}$.

2.4. DNAzyme experiments. All chemicals were purchased from Sigma-Aldrich and used without purification (including hemin (iron(III) protoporphyrin chloride, from bovine) and ABTS $\left(2,2^{\prime}\right.$ Azino-bis (3-ethylbenzothiazoline-6-sulfonic acid)). The lyophilized DNA control strands $\left(\mathrm{AG}_{4} \mathrm{~A}\right.$ and $\mathrm{AG}_{6} \mathrm{~A}$ ) were purchased from Eurogentec, Seraing, Belgium, were firstly diluted at $1000 \mu \mathrm{M}$ in deionized water (18.2 M $\Omega . c m$ resistivity). All DNA structures were prepared in a Caco.K buffer, comprised of $10 \mathrm{mM}$ lithium cacodylate buffer ( $\mathrm{pH}$ 7.2) plus $40 \mathrm{mM} \mathrm{KCl} / 60 \mathrm{mM} \mathrm{LiCl}$. Quadruplex structures were prepared by mixing $100 \mu \mathrm{L}$ of constitutive strand $(1000 \mu \mathrm{M})$ with $20 \mu \mathrm{L}$ of a lithium cacodylate buffer solution ( $100 \mathrm{mM}, \mathrm{pH} 7.2)$, plus $20 \mu \mathrm{L}$ of a $\mathrm{KCl} / \mathrm{LiCl}$ solution $(400 \mathrm{mM} / 600 \mathrm{mM})$ and $60 \mu \mathrm{L}$ of water. The final concentrations were theoretically $125 \mu \mathrm{M}$ per motif G4. The actual concentration of each DNA was determined through a dilution to $1 \mu \mathrm{M}$ theoretical concentration through UV spectral analysis at $260 \mathrm{~nm}\left(\right.$ after $5 \mathrm{~min}$ at $90^{\circ} \mathrm{C}$ ) with the following molar extinction coefficient values: $\mathrm{AG}_{4} \mathrm{~A}\left(\varepsilon=690001 . \mathrm{mol}^{-1} \cdot \mathrm{cm}^{-1}\right), \mathrm{AG}_{6} \mathrm{~A}\left(\varepsilon=892001 . \mathrm{mol}^{-1} \cdot \mathrm{cm}^{-1}\right), \mathrm{AG}_{2}-\mathrm{G}_{2} \mathrm{~A}(\varepsilon=$ $\left.690001 . \mathrm{mol}^{-1} \cdot \mathrm{cm}^{-1}\right), \mathrm{AG}_{3}-\mathrm{G}_{3} \mathrm{~A}\left(\varepsilon=892001 . \mathrm{mol}^{-1} \cdot \mathrm{cm}^{-1}\right)$. The G4 DNA structures were folded by heated $\left(90{ }^{\circ} \mathrm{C}, 5 \mathrm{~min}\right)$, gradually cooled $\left(65,60,55,50,40\right.$ and $30^{\circ} \mathrm{C}(30 \mathrm{~min} / \mathrm{step}), 25^{\circ} \mathrm{C}(2 \mathrm{~h})$ and then stored at least two days at $4{ }^{\circ} \mathrm{C}$.

2.4.1. Optimization of $\mathrm{H}_{2} \mathrm{O}_{2}$ concentration. All the experiments were carried out at $20^{\circ} \mathrm{C}$ with Caco.KTD buffer, comprised of $10 \mathrm{mM}$ lithium cacodylate buffer ( $\mathrm{pH}$ 7.2) plus $40 \mathrm{mM} \mathrm{KCl} / 60 \mathrm{mM}$ $\mathrm{LiCl}, 0.05 \%$ Triton X-100 and 0.1\% DMSO. Stock solutions were ABTS (20 mM in water), hemin (100 $\mu \mathrm{M}$ in DMSO), $\mathrm{H}_{2} \mathrm{O}_{2}(100 \mathrm{mM}$ in water) and tetramolecular $\mathrm{G} 4$ (125 $\mu \mathrm{M}$ per motif). Experimental conditions were defined as: ABTS $(1 \mathrm{mM})$, hemin $(1 \mu \mathrm{M})$, tetramolecular $\mathrm{G} 4(1 \mu \mathrm{M})$ and increasing amounts of stoichiometric oxidant $\mathrm{H}_{2} \mathrm{O}_{2}$ (from 0.2 to $1.0 \mathrm{mM}$ ). G4s and hemin mixtures in Caco.KTD buffer were stirred at room temperature for $30 \mathrm{~min}$, then ABTS were added and the DNAzyme reactions were thus initialized by the addition of $\mathrm{H}_{2} \mathrm{O}_{2}$. The experiments were carried out in 1mL-quartz cuvettes (Starna) on a JASCO V630Bio spectrophotometer with a thermally controlled six-cell holder.

2.4.2. Optimization of thermophilic DNAzyme. All the experiments were carried out with Caco.KTD buffer, comprised of $10 \mathrm{mM}$ lithium cacodylate buffer (pH 7.2) plus $40 \mathrm{mM} \mathrm{KCl} / 60 \mathrm{mM}$ $\mathrm{LiCl}, 0.05 \%$ Triton X-100 and 0.1\% DMSO. Stock solutions were ABTS (20 mM in water), hemin 
(100 $\mu \mathrm{M}$ in DMSO), $\mathrm{H}_{2} \mathrm{O}_{2}$ (20 mM in water) and tetramolecular $\mathrm{G} 4(125 \mu \mathrm{M}$ per motif). Experimental conditions were defined as: ABTS $(2 \mathrm{mM})$, hemin $(1 \mu \mathrm{M})$, tetramolecular $\mathrm{G} 4(1 \mu \mathrm{M})$ and $0.2 \mathrm{mM}$ of $\mathrm{H}_{2} \mathrm{O}_{2}$. G4s and hemin mixtures in Caco.KTD buffer were stirred at room temperature for $30 \mathrm{~min}$, then ABTS were added and the DNAzyme reactions were thus initialized by the addition of $\mathrm{H}_{2} \mathrm{O}_{2}$. The experiments were carried out in a 96-well plate on a Thermo Scientific Multiskan controlled by SkanIt software. For all of experiments, the characteristic UV-Vis signal of ABTS at $420 \mathrm{~nm}$ (recorded every 60 seconds) was collected and plotted as a function of time with OriginPro ${ }^{\circledR} 2018$ software. Raw data were firstly subtracted from the control experiment (carried out in the same conditions without G-quadruplex) and, for sake of comparison, subsequently zeroed at their very first point. The initial rates $\left(\mathrm{V}_{0}\right.$ in $\left.\mathrm{min}^{-1}\right)$ were similarly determined by fitting as a linear function the 4 very first points.

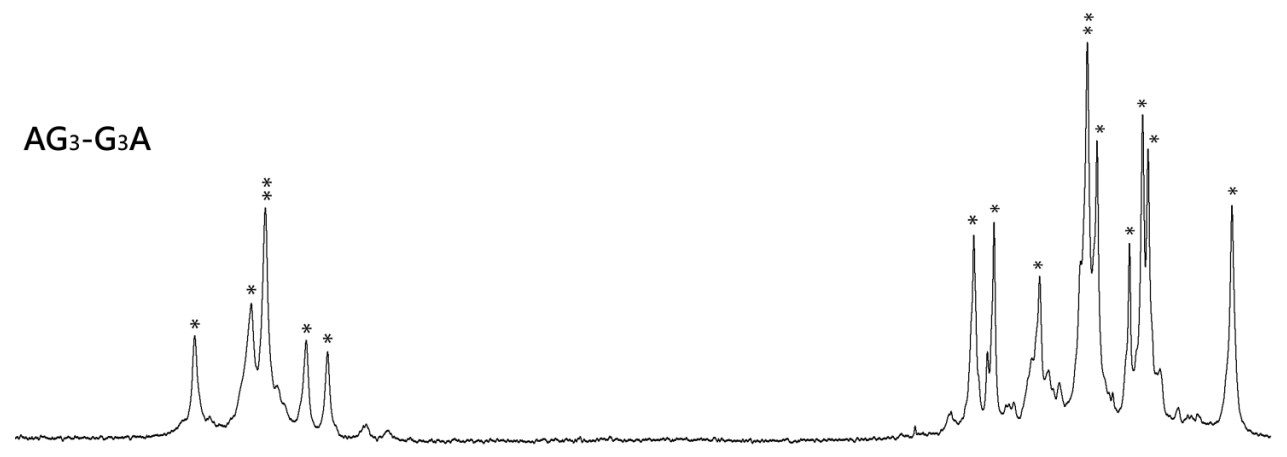

$A G_{2}-G_{2} A$

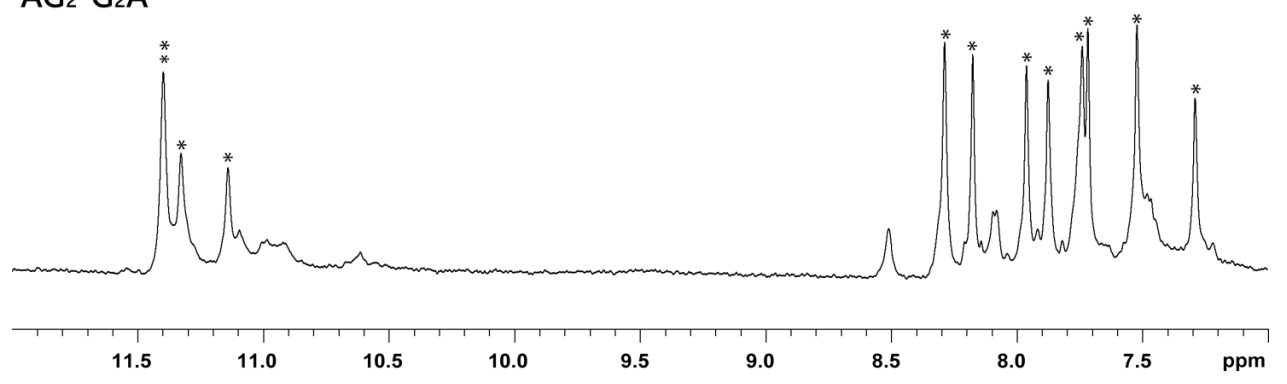

Fig. 3. Imino and aromatic proton regions of the G-quadruplex structures formed by the ODNs containing inversion of polarity sites. Stars indicate the signals of the main structures.

\section{RESULTS AND DISCUSSION}

3.1. NMR spectroscopy. The ability of $A_{2}-G_{2} A$ and $A_{3}-G_{3} A$ to form $G 4 s$ was investigated by NMR and $C D$ spectroscopy. Both sequences $A_{2}-G_{2} A$ and $A_{3}-G_{3} A$ are characterized by symmetry planes through the phosphate groups that form the inversion of polarity sites joining the two halves (Fig. 2). The occurrence of imino proton resonances in the 10.5-12.0 ppm region in ${ }^{1} \mathrm{H}-\mathrm{NMR}$ spectra is a distinctive feature of G-tetrad formation. Therefore, the inspection of this region is commonly used to gain structural insights into the G4 structure, notably its symmetry. The ${ }^{1} \mathrm{H}-\mathrm{NMR}$ spectra of $\mathrm{AG}_{2}-\mathrm{G}_{2} \mathrm{~A}$ and $\mathrm{AG}_{3}-\mathrm{G}_{3} \mathrm{~A}$ collected at $25^{\circ} \mathrm{C}$ in $\mathrm{K}^{+}$buffer (Fig. 3) show the presence of respectively 4 and 6 main signals (two of them overlap in both cases) in the region 10.5-12.0 ppm, attributable to imino protons involved in Hoogsteen hydrogen bonds of G-quartets. 8 and 10 other aromatic signals can be seen for $A_{2}-G_{2} A$ and $A_{3}-G_{3} A$, respectively, which correspond to the $\mathrm{H} 8$ of $\mathrm{dG}$ (or G-H8) and to the $\mathrm{H} 2 / \mathrm{H} 8$ of $\mathrm{dA}(\mathrm{A}-\mathrm{H} 2$ and $\mathrm{A}-\mathrm{H} 8)$. These sets of signals indicate that both $\mathrm{G} 4 \mathrm{~s}$ are formed but also that these structures are non-symmetrical, in contrast with their sequences. ${ }^{1} \mathrm{H}-\mathrm{NMR}$ spectra of $\mathrm{AG}_{4} \mathrm{~A}$ and $\mathrm{AG}_{6} \mathrm{~A}$ samples were acquired in the same conditions. The simple appearance of both ${ }^{1} \mathrm{H}-\mathrm{NMR}$ profiles indicates that the unmodified oligomers form mainly a single well-defined hydrogen-bonded conformation, showing the appropriate number of imino proton signals diagnostic of the presence of G-quadruplex structures (10.5-12.0 ppm) (Fig. S1). 
To gain further structural insights into the $G 4$-complexes formed by $A_{G_{2}}-G_{2} A$ and $A_{3}-G_{3} A, 2 D$ NMR was implemented. Most of the ${ }^{1} \mathrm{H}-\mathrm{NMR}$ resonances were assigned by means of the analysis of 2D TOCSY (data not shown) and 2D NOESY experiments (Fig. S2 and S3, Table S1). Collected data indicate that both G4s adopt a parallel-like structure, in which the 5'-5' inversion of polarity site of each strand is in the same position within the G4 structure. The 2D NOESY spectra indicate NOEs between G-H8 and A-H8 and their own $\mathrm{H}^{\prime}, \mathrm{H} 2^{\prime}$ and $\mathrm{H} 2$ " ribose protons and the H1', $\mathrm{H} 2^{\prime}$ and $\mathrm{H} 2^{\prime \prime}$ protons of the residue on the 5'-side, typical of parallel G-quadruplex structures. As expected, the path of NOE connectivities is broken at the 5'-5' inversion of polarity site. The existence of NOE sequential connectivities along the two subunits of the strand suggests that the backbones adopt a helical winding. Regarding the glycosidic torsion angles, the presence of both weak NOEs between G-H8/A-H8 and the corresponding ribose $\mathrm{H} 1$ ' and strong NOEs between G-H8/A-H8 and ribose H2' indicates that most of guanosines possess anti glycosidic conformations (in green, Fig. 2). However, for both samples, one $\mathrm{dG}$ residue adjacent to the 5'-5' inversion of polarity site was characterized by the presence of a strong NOE cross-peak involving G-H8 and $\mathrm{H}_{1}$ ' ribose proton that indicates syn glycosidic conformations for these residues, as also confirmed by the characteristic downfield shift of their H2' signals (Fig. S2, S3 and Table S1). Collectively, NMR data indicate that both G4s display a single all-syn G-tetrad, lying in the middle of the structure, adjacent to the 5'-5' inversion of polarity site (in blue, Fig. 2), as already demonstrated in similar G4s [31,32]. In both cases, NOE contacts between $\mathrm{H} 8$ and $\mathrm{H} 1$ ' of dGs flanking the 5'-5' inversion of polarity site were observed, indicative of a spatial vicinity between the all-anti and all-syn $\mathrm{G}$-tetrads. Interestingly, differently from $\mathrm{AG}_{2}-\mathrm{G}_{2} \mathrm{~A}$, $\mathrm{AG}_{3}-\mathrm{G}_{3} \mathrm{~A}$ was characterized by interstrand NOEs between A-H8 and A-H2 of adjacent strand, suggesting that $\mathrm{dA}$ residues were not randomly oriented, being close to each other and oriented in a symmetrical fashion.
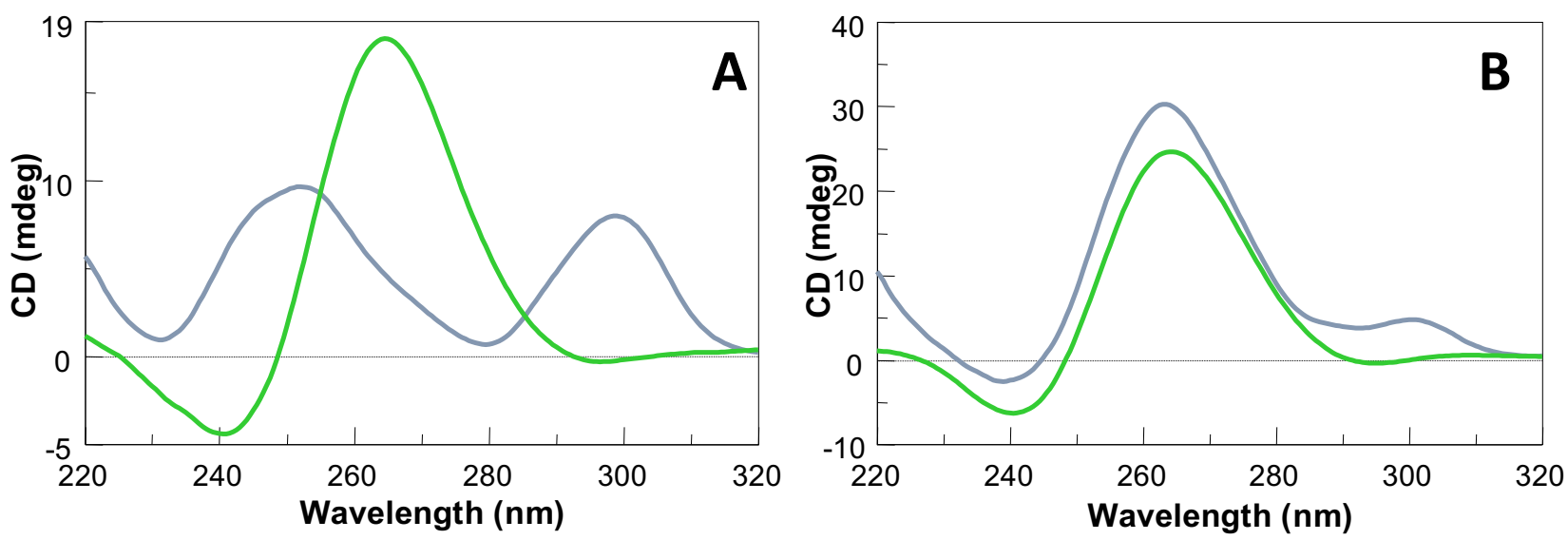

Fig. 4. $C D$ profiles of $\mathbf{A}$ ) $A_{4} A$ (green) and $A_{2}-G_{2} A$ (blue); and $\left.\mathbf{B}\right) A_{6} A$ (green) and $A_{3}-G_{3} A$ (blue) $(70 \mu M, 40 \mathrm{mM}$ $\left.\mathrm{K}^{+}, 20^{\circ} \mathrm{C}\right)$.

3.2. CD spectroscopy. To go a step further, $C D$ spectra of both $A G_{2}-G_{2} A$ and $A_{3}-G_{3} A$, along with their unmodified counterparts $\mathrm{AG}_{4} \mathrm{~A}$ and $\mathrm{AG}_{6} \mathrm{~A}$, were acquired at $20^{\circ} \mathrm{C}$ (Fig. 4). All measurements were performed at a concentration of $70 \mu \mathrm{M}$ oligonucleotide strand with a buffer containing $40 \mathrm{mM}$ $\mathrm{KCl}$. As previously reported [30], the unmodified G-quadruplexes $\mathrm{AG}_{4} \mathrm{~A}$ and $\mathrm{AG}_{6} \mathrm{~A}$ showed $\mathrm{CD}$ spectra with a maximum around $264 \mathrm{~nm}$ and a minimum around $240 \mathrm{~nm}$, typical of tetramolecular parallel G4s with all-anti G-tetrads (schematically represented in Fig. 2) [33,34]. The CD profile of $\mathrm{AG}_{2}-\mathrm{G}_{2} \mathrm{~A}$ was characterized by an unusual profile, with two positive bands of similar intensity, centred on 250 and $298 \mathrm{~nm}$ (Fig. 4A), in line with what was already described with $\mathrm{TG}_{2}-\mathrm{G}_{2} \mathrm{~T}$ [31]. On the other hand, the $C D$ profile of $\mathrm{AG}_{3}-\mathrm{G}_{3} \mathrm{~A}$ was characterized by a major positive band at $263 \mathrm{~nm}$ and a minor positive one at $298 \mathrm{~nm}$ (Fig. 4B). These data can be explained taking into account the number and nature of stacked G-tetrads. Indeed, G-tetrads are characterized by a $\mathrm{H}$-bond directionality: two stacked G-tetrads can thus be of similar or opposite directionality (homopolar $(\mathrm{H})$ 
and heteropolar (h) stacking, respectively) [34] (Fig. 2). In the case of $A_{G_{2}}-G_{2} A$ the contribution of heteropolar stacking to the CD signal is not negligible $(2 \mathrm{H}$ versus $1 \mathrm{~h}$ ), thus resulting in the unusual $\mathrm{CD}$ profile observed. On the contrary, the homopolar stacking is dominant with $\mathrm{AG}_{3}-\mathrm{G}_{3} \mathrm{~A}$ (4 $\mathrm{H}$ versus $1 \mathrm{~h}$ ), making the overall $C D$ spectrum very similar to those of $A_{4} A$ and $A_{6} A$, in which only homopolar stackings occur. Collectively, these results are in agreement with the strands orientation and tetrads arrangements provided by the NMR analysis (Fig. 3). Finally, CD-melting experiments were used to evaluate the thermal stability of this array of $4 \mathrm{G} 4 \mathrm{~s}$ (Fig. S4): none of them melted at temperature $<90^{\circ} \mathrm{C}$, thus demonstrating their very high thermal stability.
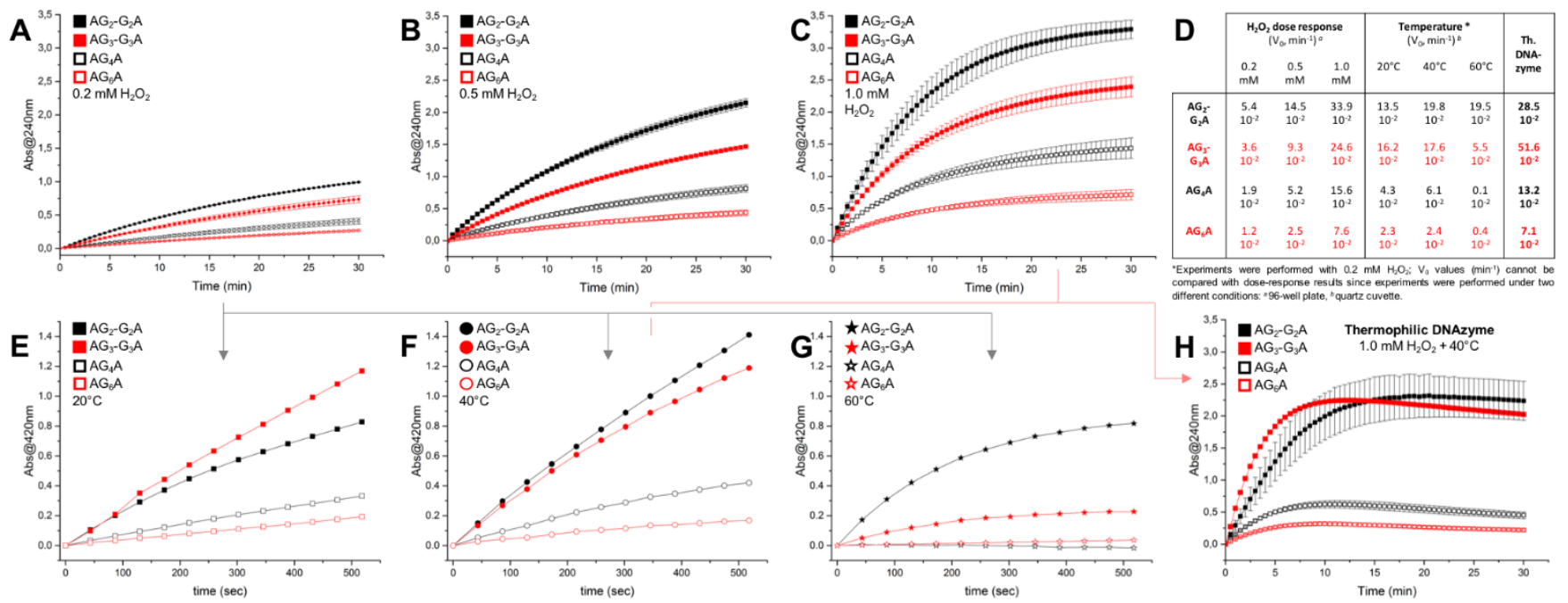

Fig. 5. DNAzyme results of experiments performed with $1 \mu \mathrm{M} G 4$ (the modified $A_{2}-G_{2} A$ and $A G_{3}-G_{3} A$ and their unmodified counterparts $\mathrm{AG}_{4} \mathrm{~A}$ and $\left.\mathrm{AG}_{6} \mathrm{~A}\right), 1 \mu \mathrm{M}$ hemin, $2 \mathrm{mM}$ ABTS and increasing amounts of stoichiometric oxidant $\mathrm{H}_{2} \mathrm{O}_{2}$ (from 0.2 to $1.0 \mathrm{mM}, \mathbf{A}-\mathbf{C}$ ) at $20^{\circ} \mathrm{C}$, or with $0.2 \mathrm{mM} \mathrm{H}_{2} \mathrm{O}_{2}$ with increasing temperature (from 20 to $60^{\circ} \mathrm{C}$, E-G). Optimized thermophilic DNAzyme was designed with $1 \mu \mathrm{M} \mathrm{G} 4,1 \mu \mathrm{M}$ hemin, $2 \mathrm{mM}$ ABTS, $1.0 \mathrm{mM} \mathrm{H}_{2} \mathrm{O}_{2}$ at $40^{\circ} \mathrm{C}(\mathbf{H})$. All experiments are performed in either 96-well plates (A-C, H) or quartz cuvettes (E-G). See Supporting Information for details. Initial velocity $\mathrm{V}_{0}$ values $\left(\mathrm{min}^{-1}\right)$ are summarized in table $\mathbf{D}$.

3.3. DNAzyme experiments. We decided to assess whether these $G 4 s$ (both the modified $A_{G_{2}}-G_{2} A$ and $A_{3}-G_{3} A$ and the unmodified $A_{4} A$ and $A_{6} A$ ) were catalytically competent. We first used the standard ABTS oxidation protocol [5] performed with a stoichiometric amount of DNA pre-catalyst and hemin $(1 \mu \mathrm{M})$ in a presence of an excess of substrate (ABTS, $2 \mathrm{mM})$, the catalysis being triggered by the addition of $\mathrm{H}_{2} \mathrm{O}_{2}(0.2 \mathrm{mM})$. As seen in Fig. 5, the ABTS oxidation was efficient as monitored via the evolution of the absorbance of $\mathrm{ABTS}^{++}$at $420 \mathrm{~nm}$ as a function of time. Interestingly, $\mathrm{AG}_{2^{-}}$ $\mathrm{G}_{2} \mathrm{~A}$ and $\mathrm{AG}_{3}-\mathrm{G}_{3} \mathrm{~A}$ displayed a better activity (initial velocity $\mathrm{V}_{0}=5.4$ and $3.610^{-2} \mathrm{~min}^{-1}$, respectively, Fig. 5D) than their unmodified counterparts (with $\mathrm{V}_{0}=1.9$ and $1.210^{-2} \mathrm{~min}^{-1}$ for $A_{4} \mathrm{~A}$ and $A_{6} \mathrm{~A}$, respectively, i.e., $\sim 3$-fold less active). Expectedly, their catalytic competences were directly function of the $\mathrm{H}_{2} \mathrm{O}_{2}$ concentration (the more, the better, Fig. 5A-C), with $\mathrm{V}_{0}$ up to 33.9 and $24.610^{-2} \mathrm{~min}^{-1}$ for $\mathrm{AG}_{2}-\mathrm{G}_{2} \mathrm{~A}$ and $\mathrm{AG}_{3}-\mathrm{G}_{3} \mathrm{~A}$, respectively, still better than their unmodified counterparts (with $\mathrm{V}_{0}$ up to 15.6 and $7.610^{-2} \mathrm{~min}^{-1}$ for $\mathrm{AG}_{4} \mathrm{~A}$ and $\mathrm{AG}_{6} \mathrm{~A}$, respectively). These results, fully in line with the double 3'-ends of modified G4s, have to be compared to the performances of intramolecular G4s. For instance, $22 \mathrm{AG} \mathrm{d}\left({ }^{5} \mathrm{AG}_{3}\left(\mathrm{~T}_{2} \mathrm{AG}_{3}\right)_{3}{ }^{3}\right)$, which was studied as a possible biologically relevant catalytic G4, displayed lower performances $\left(\mathrm{V}_{0}=2.710^{-2} \mathrm{~min}^{-1}\right)$ under comparable experimental conditions ( 1 $\mu \mathrm{M}$ DNA, $1 \mu \mathrm{M}$ hemin, $2 \mathrm{mM}$ ABTS and $0.6 \mathrm{mM} \mathrm{H}_{2} \mathrm{O}_{2}$ ) [35]. However, specially dedicated intramolecular $\mathrm{G} 4$ such as the series of $\mathrm{G} 3 \mathrm{~T} \mathrm{~d}\left({ }^{5} \mathrm{G}_{3} \mathrm{TG}_{3} \mathrm{TG}_{3} \mathrm{TG}_{3}{ }^{3}\right)$ derivatives developed by Zhou et $a l$. were found more efficient, with $\mathrm{V}_{0}$ up to $40.010^{-2} \mathrm{~min}^{-1}$ for lower catalyst loading $(0.4 \mu \mathrm{M} \mathrm{DNA}$, $0.8 \mu \mathrm{M}$ hemin, $0.6 \mathrm{mM}$ ABTS and $0.6 \mathrm{mM} \mathrm{H}_{2} \mathrm{O}_{2}$ ) [7]. However, these results cannot be directly compared to the tetramolecular $\mathrm{G} 4$ folded from the $\mathrm{d}\left({ }^{5^{\prime}} \mathrm{AG}_{5} \mathrm{~A}^{3}\right)$ used as thermophilic DNAzyme [30]: in these experiments, AG5A was found highly efficient at room temperature (with $\mathrm{V}_{0}=60.010^{-2} \mathrm{~min}^{-}$ ${ }^{1}$ ) at a concentration of $0.86 \mu \mathrm{M}$ DNA, upon addition of $1.72 \mu \mathrm{M}$ hemin, $1.28 \mathrm{mM}$ ABTS and 1.28 
$\mathrm{mM} \mathrm{H} \mathrm{H}_{2} \mathrm{O}_{2}$. We next decided to assess whether $\mathrm{AG}_{2}-\mathrm{G}_{2} \mathrm{~A}$ and $\mathrm{AG}_{3}-\mathrm{G}_{3} \mathrm{~A}$ might behave as thermophilic G4-DNAzyme, performing catalysis at 20,40 and $60^{\circ} \mathrm{C}$ (Fig. 5E-G) under our predefined conditions (vide supra). The catalytic proficiencies of these $\mathrm{G} 4$ systems increased with the temperature, to be optimal at $40^{\circ} \mathrm{C}\left(\mathrm{V}_{0}=19.8\right.$ and $17.610^{-2} \mathrm{~min}^{-1}$ for $\mathrm{AG}_{2}-\mathrm{G}_{2} \mathrm{~A}$ and $\mathrm{AG}_{3}-\mathrm{G}_{3} \mathrm{~A}$, respectively, versus 6.1 and $2.410^{-2} \mathrm{~min}^{-1}$ for $\mathrm{AG}_{4} \mathrm{~A}$ and $\mathrm{AG}_{6} \mathrm{~A}$, respectively). These results highlighted that a subtle equilibrium has to be reached when designing thermophilic DNAzymes, dealing with temperaturepromoted catalysis, G4 thermal stability and efficient hemin binding that likely involves the wreath of adenine on the 3'-ends of the $\mathrm{G} 4 \mathrm{~s}$. We finally decided to combine optimal $\mathrm{H}_{2} \mathrm{O}_{2}$ concentration (1.0 $\mathrm{mM})$ and temperature $\left(40^{\circ} \mathrm{C}\right)$ to design new thermophilic DNAzymes made of G4s embedding $5^{\prime}-5^{\prime}$ inversion of polarity site $(\mathrm{Fig} .5 \mathrm{H})$ that proved efficient $\left(\mathrm{V}_{0}=28.510^{-2} \mathrm{~min}^{-1}\right.$ for $\left.A_{G_{2}}-\mathrm{G}_{2} \mathrm{~A}\right)$ and very efficient $\left(V_{0}=51.610^{-2} \mathrm{~min}^{-1}\right.$ for $\left.A_{3}-G_{3} A\right)$, especially with regard to their unmodified counterparts $\left(\mathrm{V}_{0}=13.2\right.$ and $7.110^{-2} \mathrm{~min}^{-1}$ for $\mathrm{AG}_{4} \mathrm{~A}$ and $\mathrm{AG}_{6} \mathrm{~A}$, respectively, i.e., up to 7-fold less active).

Overall, the systematic comparison of the performances of the modified $A_{2}-G_{2} A / A_{3}-G_{3} A$ versus the unmodified $\mathrm{AG}_{4} \mathrm{~A} / \mathrm{AG}_{6} \mathrm{~A}$ precatalysts clearly shows that the unmodified $\mathrm{G} 4 \mathrm{~s}$ are systematically less active than the modified G4s, whatever the experimental conditions they are used in (concentration, temperature, etc.). These results thus confirmed the relevance of our chemical modification approach, combining 5'-5' inversion of polarity site and introduction of 3'-end dA caps, and provide a solid basis for designing ever more efficient DNA-based molecular devices.

\section{Conclusions}

The discovery of catalytic DNAs has spurred promising biotechnological developments thanks to the unique properties of nucleic acids in terms of chemical versatility and programmable functionalities [36]. Nucleic acids indeed have key advantages over protein enzymes (size, synthetic access, tunable sequences) but their catalytic properties do not still reach the performances of their proteinic counterparts. This lower catalytic proficiency might originate in less structurally defined active sites and cofactor binding pockets in nucleic acids pre-catalysts. Catalytic quadruplexes $(\mathrm{G} 4 \mathrm{~s})$ offer a unique opportunity to tackle this issue, thanks to external G-quartets that constitute more defined catalytic centers. When combined with hemin, $\mathrm{G} 4 /$ hemin systems behave as hemoproteins (e.g., peroxidases) capable of performing $\mathrm{H}_{2} \mathrm{O}_{2}$-promoted catalytic oxidations. A great deal of research has been devoted to improve the performances of catalytic G4s, with a particular focus on their sequences (that govern their topology and stability) and the hemin-binding sites (the external G-quartet and surrounding nucleobases). Here, we report on a new strategy implemented to increase the catalytic potential of G4s via a modification of their inner backbones $\left(5^{\prime}-5^{\prime}\right.$ inversion of polarity site in the middle of the G4-forming DNA strands). This chemical modification uniquely allows for obtaining G4s with two identical external G-quartets, i.e., two 3'-ends, known to be critical for hemin binding and catalysis. In light of literature precedents, we also introduced dA caps on top of the 3'-ends, given that these additional nucleobases actively participate to hemin fixation and activation. Our optimal G4 systems $A_{G_{2}}-G_{2} A$ and $A_{3}-G_{3} A$ were shown to display far better catalytic performances (in the model ABTS oxidation reaction) than their unmodified counterparts $A_{4} A$ and $A_{6} A$, thereby lending credence to the relevance of our strategy. We also showed that their thermal stability allows for being used as thermophilic DNAzymes, further increasing the interest and scope of this new class of catalytic G4s. These results thus add another string to the bow of chemical modifications that make G4 pre-catalysts still more effective. More examples of G4s with 5'-5' inversion of polarity site will be soon developed to bring catalytic G4s ever closer to the performances of related hemoproteins.

Acknowledgments. This work was financially supported by the Department of Pharmacy, University of Naples Federico II, Fondo di finanziamento per le attività base di ricerca (FFABR 2017) for V.E. and A.V., the CNRS (D.M.) and the Agence Nationale de la Recherche (ANR-17-CE17-0010-01 for P.L. and D.M.). This project is part of the project "Pharmaco-imagerie \& agents théranostiques" supported by the Université de Bourgogne and Conseil Régional de Bourgogne (PARI) and the European Union (PO FEDER-FSE Bourgogne 2014/2020 programs). 


\section{REFERENCES}

[1] D. Sen, L.C.H. Poon, RNA and DNA complexes with hemin [Fe(III) heme] are efficient peroxidases and peroxygenases: how do they do it and what does it mean?, Crit. Rev. Biochem. Mol. Biol. 46 (2011) 478-492. doi: 10.3109/10409238.2011.618220

[2] Y. Li, D. Sen, A catalytic DNA for porphyrin metallation, Nat. Struct. Biol. 3 (1996) 743747. doi:10.1038/nsb0996-743.

[3] P. Travascio, Y.Li, D. Sen, DNA-enhanced peroxidase activity of a DNA aptamer-hemin complex, Chem. Biol. 5 (1998) 505-517. doi:10.1016/S1074-5521(98)90006-0.

[4] P. Travascio, P.K. Witting, A.G. Mauk, D. Sen, The peroxidase activity of a hemin-DNA oligonucleotide complex: Free radical damage to specific guanine bases of the DNA, J. Am. Chem. Soc. 123 (2001) 1337-1348. doi:10.1021/ja0023534.

[5] L. Stefan, F. Denat, D. Monchaud, Insights into how nucleotide supplements enhance the peroxidase-mimicking DNAzyme activity of the G-quadruplex/hemin system, Nucleic Acids Res. 40 (2012) 8759-8772. doi:10.1093/nar/gks581.

[6] H. Shimizu, H. Tai, K. Saito, T. Shibata, M. Kinoshita, Y. Yamamoto, Characterization of the Interaction between Heme and a Parallel G-Quadruplex DNA Formed from d(TTAGGGT), Bull. Chem. Soc. Jpn. 88 (2015) 644-652. doi:10.1246/bcsj.20140374.

[7] J. Chen, Y. Zhang, M. Cheng, Y. Guo, J. Šponer, D. Monchaud, J.L. Mergny, H. Ju, J. Zhou, How Proximal Nucleobases Regulate the Catalytic Activity of G-Quadruplex/Hemin DNAzymes, ACS Catal. 8 (2018) 11352-11361. doi:10.1021/acscatal.8b03811.

[8] K. Saito, H. Tai, H. Hemmi, N. Kobayashi, Y. Yamamoto, Interaction between the heme and a G-quartet in a heme-DNA complex, Inorg. Chem. 51 (2012) 8168-8176. doi:10.1021/ic3005739.

[9] J.L. Mergny, D. Sen, DNA quadruple helices in nanotechnology, Chem. Rev. 119 (2019) 6290-6325. doi:10.1021/acs.chemrev.8b00629.

[10] B.T. Roembke, S. Nakayama, H.O. Sintim, Nucleic acid detection using G-quadruplex amplification methodologies, Methods. 64 (2013) 185-198. doi:10.1016/j.ymeth.2013.10.003.

[11] F. Wang, C.H. Lu, I. Willner, From cascaded catalytic nucleic acids to enzyme-DNA nanostructures: Controlling reactivity, sensing, logic operations, and assembly of complex structures, Chem. Rev. 114 (2014) 2881-2941. doi:10.1021/cr400354z.

[12] Z. Hu, Z. Suo, W. Liu, B. Zhao, F. Xing, Y. Zhang, L. Feng, DNA conformational polymorphism for biosensing applications, Biosens. Bioelectron. 131 (2019) 237-249. doi:10.1016/j.bios.2019.02.019.

[13] L. Gong, Z. Zhao, Y.F. Lv, S.Y. Huan, T. Fu, X.B. Zhang, G.L. Shen, R.Q. Yu, DNAzymebased biosensors and nanodevices, Chem. Commun. 51 (2015) 979-995. doi:10.1039/c4cc06855f.

[14] J. Kosman, B. Juskowiak, Peroxidase-mimicking DNAzymes for biosensing applications: A review, Anal. Chim. Acta. 707 (2011) 7-17. doi:10.1016/j.aca.2011.08.050.

[15] W. Zhou, R. Saran, J. Liu, Metal Sensing by DNA, Chem. Rev. 117 (2017) 8272-8325. doi:10.1021/acs.chemrev.7b00063.

[16] M.R. Saidur, A.R.A. Aziz, W.J. Basirun, Recent advances in DNA-based electrochemical biosensors for heavy metal ion detection: A review, Biosens. Bioelectron. 90 (2017) 125139. doi:10.1016/j.bios.2016.11.039.

[17] S. Zhan, Y. Wu, L. Wang, X. Zhan, P. Zhou, A mini-review on functional nucleic acidsbased heavy metal ion detection, Biosens. Bioelectron. 86 (2016) 353-368. doi:10.1016/j.bios.2016.06.075.

[18] D.L. Ma, D.S.H. Chan, B.Y.W. Man, C.H. Leung, Oligonucleotide-based luminescent detection of metal ions, Chem. - An Asian J. 6 (2011) 986-1003. doi:10.1002/asia.201000870.

[19] T. Kilic, A. Erdem, M. Ozsoz, S. Carrara, microRNA biosensors: Opportunities and 
challenges among conventional and commercially available techniques, Biosens. Bioelectron. 99 (2018) 525-546. doi:10.1016/j.bios.2017.08.007.

[20] M. Mahdiannasser, Z. Karami, An innovative paradigm of methods in microRNAs detection: highlighting DNAzymes, the illuminators, Biosens. Bioelectron. 107 (2018) 123-144. doi:10.1016/j.bios.2018.02.020.

[21] D.M. Kong, Factors influencing the performance of G-quadruplex DNAzyme-based sensors, Methods. 64 (2013) 199-204. doi:10.1016/j.ymeth.2013.07.013.

[22] L. Zhu, C. Li, Z. Zhu, D. Liu, Y. Zou, C. Wang, H. Fu, C.J. Yang, In vitro selection of highly efficient G-quadruplex-based DNAzymes, Anal. Chem. 84 (2012) 8383-8390. doi:10.1021/ac301899h.

[23] J. Chen, Y. Guo, J. Zhou, H. Ju, The Effect of Adenine Repeats on G-quadruplex/hemin Peroxidase Mimicking DNAzyme Activity, Chem. - A Eur. J. 23 (2017) 4210-4215. doi:10.1002/chem.201700040.

[24] W. Li, Y. Li, Z. Liu, B. Lin, H. Yi, F. Xu, Z. Nie, S. Yao, Insight into G-quadruplex-hemin DNAzyme/RNAzyme: Adjacent adenine as the intramolecular species for remarkable enhancement of enzymatic activity, Nucleic Acids Res. 44 (2016) 7373-7384. doi:10.1093/nar/gkw634.

[25] T. Chang, H. Gong, P. Ding, X. Liu, W. Li, T. Bing, Z. Cao, D. Shangguan, Activity Enhancement of G-Quadruplex/Hemin DNAzyme by Flanking d(CCC), Chem. - A Eur. J. 22 (2016) 4015-4021. doi:10.1002/chem.201504797.

[26] D.M. Kong, J. Xu, H.X. Shen, Positive effects of ATP on G-quadruplex-hemin DNAzymemediated reactions, Anal. Chem. 82 (2010) 6148-6153. doi:10.1021/ac100940v.

[27] L. Stefan, F. Denat, D. Monchaud, Deciphering the DNAzyme activity of multimeric quadruplexes: Insights into their actual role in the telomerase activity evaluation assay, J. Am. Chem. Soc. 133 (2011) 20405-20415. doi:10.1021/ja208145d.

[28] C. Qi, N. Zhang, J. Yan, X. Liu, T. Bing, H. Mei, D. Shangguan, Activity enhancement of Gquadruplex/hemin DNAzyme by spermine, RSC Adv. 4 (2014) 1441-1448. doi:10.1039/c3ra45429k.

[29] E. Golub, H.B. Albada, W.C. Liao, Y. Biniuri, I. Willner, Nucleoapzymes: Hemin/GQuadruplex DNAzyme-Aptamer Binding Site Conjugates with Superior Enzyme-like Catalytic Functions, J. Am. Chem. Soc. 138 (2016) 164-172. doi:10.1021/jacs.5b09457.

[30] Y. Guo, J. Chen, M. Cheng, D. Monchaud, J. Zhou, H. Ju, A Thermophilic Tetramolecular G-Quadruplex/Hemin DNAzyme, Angew. Chemie - Int. Ed. 56 (2017) 16636-16640. doi:10.1002/anie.201708964.

[31] V. Esposito, A. Virgilio, A. Randazzo, A. Galeone, L. Mayol, A new class of DNA quadruplexes formed by oligodeoxyribonucleotides containing a 3'-3' or 5'-5' inversion of polarity site., Chem. Commun. (Camb). (2005) 3953-3955. doi:10.1039/b504455c.

[32] V. Esposito, A. Virgilio, A. Pepe, G. Oliviero, L. Mayol, A. Galeone, Effects of the introduction of inversion of polarity sites in the quadruplex forming oligonucleotide TGGGT, Bioorganic Med. Chem. 17 (2009) 1997-2001. doi:10.1016/j.bmc.2009.01.027.

[33] J. Kypr, I. Kejnovská, D. Renčiuk, M. Vorlíčková, Circular dichroism and conformational polymorphism of DNA, Nucleic Acids Res. 37 (2009) 1713-1725. doi:10.1093/nar/gkp026.

[34] S. Masiero, R. Trotta, S. Pieraccini, S. De Tito, R. Perone, A. Randazzo, G.P. Spada, A nonempirical chromophoric interpretation of CD spectra of DNA G-quadruplex structures., Org. Biomol. Chem. 8 (2010) 2683-2692. doi:10.1039/c003428b.

[35] L. Stefan, D. Duret, N. Spinelli, E. Defrancq, D. Monchaud, Closer to nature: An ATPdriven bioinspired catalytic oxidation process, Chem. Commun. 49 (2013) 1500-1502. doi:10.1039/c2cc38317a.

[36] J. Liu, Z. Cao, Y. Lu, Functional nucleic acid sensors, Chem. Rev. 109 (2009) 1948-1998. doi:10.1021/cr030183i. 